\title{
Tertiary Follicular Growth Wave Dynamics after Oestrus Synchronization and Superovulation in Ewes and Goats
}

\author{
I. MARAČEK, M. KRAJNIČÁKOVÁ, M. KOSTECKÝ, G. GRÉSEROVÁ, I. VALOCKÝ1 \\ Research Institute of Veterinary Medicine UVM, Košice, \\ ${ }^{1}$ University of Veterinary Medicine, Košice, Slovak Republic
}

Received July 15, 2002

Accepted November 18, 2002

\begin{abstract}
Maraček I., M. Krajničáková, M. Kostecký, G. Gréserová, I. Valocký: Tertiary Follicular Growth Wave Dynamics after Oestrus Synchronization and Superovulation in Ewes and Goats. Acta Vet. Brno 2002, 71: 481-486.

The quality and quantity of morphological and functional changes in ovarian tertiary follicles during their growth and development waves after synchronisation of oestrus and superovulation treatment is described. Within 48 and $120 \mathrm{~h}$ after injection of $125 \mu \mathrm{g}$ cloprostenol simultaneous amplification of healthy non-atretic tertiary follicles as well as those recruited and selected as dominant on the ovarian surface was observed. The mean size of the largest growing dominant, i.e., ovulatory follicle significantly increased in ewes 24 and $48 \mathrm{~h}$ after cloprostenol administration compared not only to controls but also to experimental groups at 72 and $120 \mathrm{~h}$ after luteolytic treatment. Eleven $(73.3 \%)$ goats and $45(88.24 \%)$ ewes were found to respond to superovulatory treatment. Significant differences $(P<0.01)$ in ovulation response were noted between FSH $(9.6$ $\pm 3.8)$ and PMSG $(4.6 \pm 1.1)$ preparations in ewes. After superovulatory treatment the oestradiol$17 \beta$ levels in follicular fluid of the selected dominant follicles increased significantly as compared to the large atretic follicles $(P<0.001)$. Oestrus synchronisation in ewes was carried out by cloprostenol induction of the new follicular wave. These results suggest that luteolysis has a key role both in the process of recruitment and in the induction of selection during folliculogenesis in ewes. Evaluation of the superovulatory response in ewes and goats demonstrates that FSH- and PMSG-based preparations affect follicles after recruitment in the process of selection.
\end{abstract}

Ovarian follicles, recruitment, selection, cloprostenol, chlorsuperlutin, FSH, PMSG

The ovary of an adult ewe contains 12 000-86 000 primordial follicles and 100-400 growing follicles of which 10-40 are visible on the ovarian surface (Cahill et al. 1979; Mc Natty et al. 1982; et al. 1985). The differentiation of one mature preovulatory follicle, the so-called dominant follicle, is the result of a complex interaction between the cohort of ovarian follicles on the growth trajectory and the hypothalamo-pituitary system with intraovarian endo-, para- and autocrine regulatory factors and mechanisms (Dri ancourt et al. 1985; Murdoch 1985, 1988; Erickson 1986, Presl and Bukovský 1989ab; Greenwald and Terranova 1988; Driancourt 1994). Differentiation of the dominant tertiary follicle is a two-stage process (Di Zerega and Hodgen 1981) in which, as a result of gonadotrophic stimulation, anthral follicles are advantaged by more intensive growth.

The development of normal healthy tertiary follicles with a diameter surpassing $2 \mathrm{~mm}$ is termed recruitment and the developing, growing anthral follicles with a diameter of $2-5 \mathrm{~mm}$ are termed recruited. Differentiation and maturation advance to the process of selection of those tertiary follicles that reach a diameter of more than $5 \mathrm{~mm}$. This process of selection usually results in one, seldom in two and only exceptionally in multiple, 3 or 4 dominant ovulatory follicles. All other follicles undergo atresia (Driancourt et al. 1985; Murd och 1985, 1988; Doležel 1995ab). Literary data point at the fact that in sheep, the process of recruitment occurs at a variable time around luteolysis (Mc Natty et al. 1981, 1982; Murdoch 1985).

Address for correspondence:

Prof. MVDr. I. Maraček, DrSc.

Prof. MVDr. I. Maraček, DIS

Department of Physiology

Komenského 73, 04181 Košice, Slovak Republic
Phone: +42155638249

Fax: +421556331853

http://www.vfu.cz/acta-vet/actavet.htm 
In this work quantitative analysis was carried out of the tertiary follicular populations in the ovaries of sheep and goats from the viewpoint of the process of follicle recruitment and selection after (1) luteolytic treatment of Czigaya sheep with a preparation on the basis of cloprostenol and (2) superovulation induction by means of FSH or PMSG preparations in Merino sheep and white goats. It was our aim to materialize and extend our knowledge (1) of the selection of the dominant ovulatory tertiary follicle and (2) of the influence of cloprostenol racemate-, follitropin- and pregnant mare serum gonadotropin-based preparations upon tertiary follicles in sheep and goats.

\section{Materials and Methods}

Experiment 1

Observations and experiments with the cloprostenol racemate-based preparation were carried out during the breeding (mating) season in the autumn oestrous period. Forty-one Slovak Czigaya sheep aged 2 - 5 years and bred under standard commercial conditions were divided into 5 groups. Group I $(n=6)$ comprised the control animals on day $10-12$ of their sexual cycles. In the luteal phase of their oestrous cycles the experimental animals were divided into 4 groups, viz, Groups II $(n=8)$, III $(n=9)$, IV $(n=8)$ and V $(n=10)$; they were i. m. treated with 125 $\mu \mathrm{g}$ cloprostenol in $0.5 \mathrm{ml}$ of Oestrophan inj. ad us. vet. (Léčiva Prague, Czech Rep.) per animal. The ewes in Groups II - V were killed 24, 48, 72 and $120 \mathrm{~h}$ after treatment, respectively. After excision, the ovaries were fixed in $10 \%$ neutral formalin for $48 \mathrm{~h}$; then, surface follicles were counted and measured. Fixation of the ovarian tissues was followed by cutting the ovaries into $4 \mathrm{~mm}$ segments that were postfixed for 5 days, rinsed, dehydrated and subsequently paraffin-embedded. Five-to-seven $\mu \mathrm{m}$ thick simultaneous transverse serial sections made at 150-210 $\mu \mathrm{m}$ intervals were stained with haematoxylin-eosin or the PAS reaction with nuclear staining using Harris haematoxylin. Qualitative evaluation of the developing growing and healthy follicles and their differentiation from the atretic ones as well as quantitative evaluations were made in the way described earlier (Maraček et al. 1983; 1993). According to this classification there are three stages of atretic follicles in addition to normal developing tertiary follicles, i. e., 1 - early atresia, 2 - definite atresia and 3 - late atresia. A tertiary follicle in early atresia shows the following histological features: the membrana limitans interna disappears, atretic bodies are formed, the membrana basalis disappears or is absent. In definite atresia the follicle is subjected to many changes that prevent the production of the ovum. In this stage of atresia collapsing, contracting, cystic and luteinized cystic atresia can be differentiated. The stage of late atresia reveals changes typical of the terminal stage of the individual types of definite atresia with a typical decrease in size and lumen.

Experiment 2

In the second experiment we evaluated the ovaries of 51 ewes of the Slovak Merino breed and 15 Slovak white goats. For superovulation treatment, folitropin (FSH) in the preparation Folicotropin inj. ad us. vet. (Léčiva, Prague, Czech Rep.) $(n=24)$ or pregnant mare serum gonadotropin (PMSG) in the preparations Folligon (Intervet) $(n=6)$ and Sergon (Bioveta, a. s., Czech Rep.) $(\mathrm{n}=21)$ were used, respectively. The superovulation treatment was carried out after synchronization of the oestrus by means of chlorsuperlutin (Agelin ad us. vet., Spofa, Prague, Czech Rep.). The schemes for the preparation of donors and recipients were designed in the way described earlier (Maraček et al. 1989; et al. 1997). The ovarian tertiary surface follicles and ovulation (the number of corpus luteum) were evaluated at washing up and collection of oocytes and zygotes during laparotomy or laparoscopy.

\section{Experiment 3}

In the third experiment we determined the level of oestradiol-17 $\beta\left(E_{2}\right)$ and progesterone in the follicular fluid of the largest follicles from the ovaries of 9 Slovak white goats. Follicular fluid was aspirated from the largest follicles on the 2nd day after PMSG ( $=4$, goats) administration or after the last injection of FSH $(\mathrm{n}=5$, goats). After centrifugation at $3000 \mathrm{~g}$ the supernatant was stored at $-18^{\circ} \mathrm{C}$ until processing. In order to determine oestradiol-17ß and progesterone levels in the follicular fluid the RIA-test-Estra (SI-125-9) and RIA-test-Prog (SI-125-6) commercial kits manufactured by Huma-Lab Košice (Slovak Republic) were used, respectively. The fluid was diluted with $1.5 \%$ bovine gammaglobulin. The intra- and inter-assay coefficient of variation presented 10.1 and $13.3 \%$, respectively, for the oestradiol kit and 11.4 and $13.7 \%$, respectively, for the progesterone kit.

After determining the significance of differences between the standard deviations by the F-test (Sokal and Rohlf 1969) the significance of differences between the two experimental groups was calculated by the unpaired Student's $t$-test.

\section{Results}

In Table 1, the changing numbers are summarized of the population in the single follicular classes in both ovaries as observed in Czigaya sheep in the luteal phase of their cycles and after cloprostenol-induced luteolysis. Although the individual tertiary follicle classes varied 
Table 1

Population of ovarian tertiary follicles in both ovaries during the luteal phase of the oestrous cycle and after cloprostenol-induced luteolysis in sheep

\begin{tabular}{|c|c|c|c|c|}
\hline \multirow{2}{*}{ Group } & \multicolumn{3}{|c|}{ Tertiary follicles (n) } & \multirow{2}{*}{$\begin{array}{c}\text { Ovulation } \\
\text { rate }\end{array}$} \\
\cline { 2 - 5 } & $\begin{array}{c}\text { Total } \\
\text { Mean } \pm \text { SD }\end{array}$ & $\begin{array}{c}\text { Surface } \\
\text { Mean } \pm \text { SD }\end{array}$ & $\begin{array}{c}\text { Selected } \\
\text { Mean } \pm \text { SD }\end{array}$ & 1.17 \\
\hline Control (day 10-12) & $30.3 \pm 4.5$ & $14.9 \pm 3.0$ & $2.67 \pm 1.2$ & 1.25 \\
\hline $24 \mathrm{~h}$ & $26.9 \pm 7.2$ & $14.5 \pm 1.9$ & $3.13 \pm 1.4$ & 1.33 \\
\hline $48 \mathrm{~h}$ & $31.4 \pm 3.3$ & $18.2 \pm 3.4$ & $3.67 \pm 1.1$ & 1.37 \\
\hline $72 \mathrm{~h}$ & $25.9 \pm 5.1$ & $14.2 \pm 1.8$ & $3.88 \pm 0.9$ & 1.20 \\
\hline $120 \mathrm{~h}$ & $23.7 \pm 7.5$ & $12.8 \pm 2.6$ & $4.70 \pm 1.9$ & \\
\hline
\end{tabular}

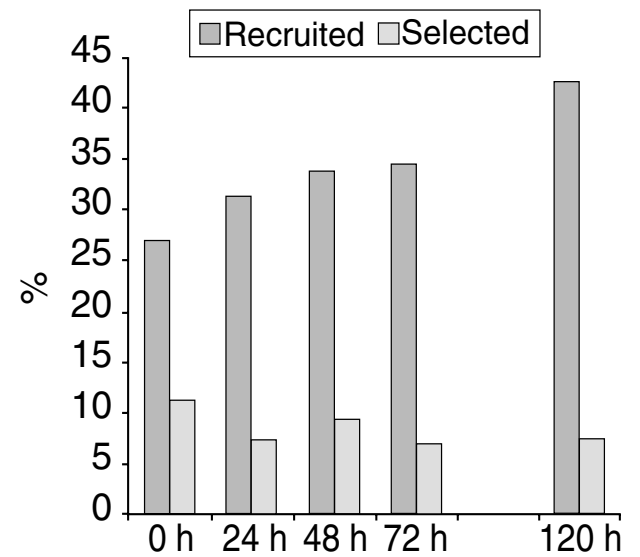

Fig. 1. Percentage of recruited and selected ovarian surface tertiary follicles considerably, it is notable that $48 \mathrm{~h}$ after luteolytic treatment the overall number of recruited tertiary follicles, and that of surface follicles in particular, increased.

Forty-eight hours after cloprostenol treatment the increased relative number of tertiary follicles smaller than $2 \mathrm{~mm}$ points at the occurrence of a new cohort of secondary and tertiary follicles on the trajectory of growth and development. Luteolytic treatment promotes the differentiation of the largest tertiary follicle and its stimulatory effects culminate 48 hours after administration.

In Fig. 1, the percentage of tertiary recruited and selected follicles counted on the ovarian surface in Czigaya sheep after

Table 2

Response of ovarian tertiary follicles on both ovaries after superovulatory treatment of sheep and goats

\begin{tabular}{|c|c|c|c|c|}
\hline \multirow[b]{2}{*}{$\begin{array}{c}\text { Pharmaceutical } \\
\text { preparation }\end{array}$} & \multirow[b]{2}{*}{$\begin{array}{l}\text { Number } \\
\text { of animals } \\
\text { (n) }\end{array}$} & \multicolumn{2}{|c|}{ Response of ovaries } & \multirow[b]{2}{*}{$\begin{array}{l}\text { Washed-up } \\
\text { oocyts } \\
\text { and zygotes }\end{array}$} \\
\hline & & $\begin{array}{c}\text { Follicles } \\
>2 \mathrm{~mm}+\mathrm{CL}\end{array}$ & $\begin{array}{c}\text { Corpus } \\
\text { luteum(CL) } \\
\text { (ovulation) }\end{array}$ & \\
\hline \multicolumn{5}{|c|}{ EWES } \\
\hline $\begin{array}{l}\text { Folicotropin (Léčiva, } \\
\text { Prague ) - FSH }\end{array}$ & 24 & $\begin{array}{c}282 \\
11.8 \pm 3.4\end{array}$ & $\begin{array}{c}227(80.6 \%) \\
9.5 \pm 3.8\end{array}$ & $\begin{array}{c}142(62.6 \%) \\
5.9 \pm 2.6\end{array}$ \\
\hline $\begin{array}{l}\text { Folligon ( Intervet ) } \\
\text { - PMSG }\end{array}$ & 6 & $\begin{array}{c}63 \\
10.5 \pm 2.3\end{array}$ & $\begin{array}{c}37(58.7 \%) \\
6.2 \pm 2.5\end{array}$ & $\begin{array}{c}19(51.4 \%) \\
3.2 \pm 2.2\end{array}$ \\
\hline Sergon (Bioveta) - PMSG & 21 & $\begin{array}{c}154 \\
7.3 \pm 1.4\end{array}$ & $\begin{array}{c}97(63.0 \%) \\
4.6 \pm 1.1\end{array}$ & $\begin{array}{c}68(70.1 \%) \\
3.0 \pm 0.9\end{array}$ \\
\hline \multicolumn{5}{|c|}{ GOATS } \\
\hline $\begin{array}{l}\text { Folicotropin (Léčiva, } \\
\text { Prague ) - FSH }\end{array}$ & 7 & $\begin{array}{c}88 \\
12.6 \pm 1.6\end{array}$ & $\begin{array}{c}55(62.5 \%) \\
7.9 \pm 1.8\end{array}$ & $\begin{array}{c}36(65.5 \%) \\
5.1 \pm 1.1\end{array}$ \\
\hline Sergon (Bioveta) - PMSG & 8 & $\begin{array}{c}75 \\
9.4 \pm 1.9\end{array}$ & $\begin{array}{l}27(36.0) \\
3.4 \pm 1.4\end{array}$ & $\begin{array}{l}22(81.5) \\
2.8 \pm 1.2\end{array}$ \\
\hline
\end{tabular}




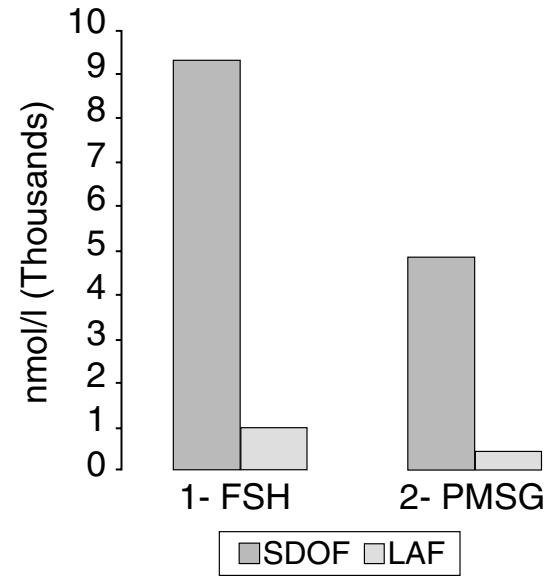

Fig. 2. Oestradiol levels in the follicular fluid of selected dominant ovarian follicles (SDOF) and large atretic follicles (LAF)

cloprostenol treatment is given. Twentyfour and 48 hours after luteolytic treatment multiplication of the recruited follicles was observed. Changes in the number of selected follicles revealed greater variation than in the number of the recruited ones.

Eleven $(73.3 \%)$ of 15 goats and $45(88.24 \%)$ of 51 ewes were found to respond to superovulatory treatment. In Table 2, the response of ovarian tertiary follicles to superovulatory treatment in Slovak Merino sheep and Slovak white goats is summarized. In sheep as well as in goats significant differences $(P<0.01)$ were observed in the mean number of ovulations induced by FSH and PMSG treatment.

The mean levels of oestradiol-17ß in the follicular fluid of the selected dominant follicles and of the large atretic follicles in goats are presented in Fig. 2. After superovulatory treatment oestradiol-17ß $\left(E_{2}\right)$ levels in the follicular fluid of the selected healthy dominant ovarian follicles significantly increased $(P<0.001)$ as compared to the large atretic follicles.

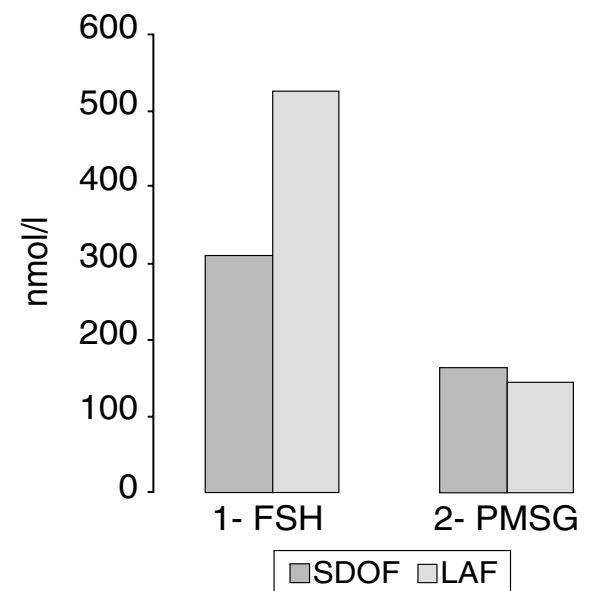

Fig. 3. Progesterone levels in the follicular fluid of selected dominant ovarian follicles (SDOF) and large atretic follicles.

The mean progesterone levels in the follicular fluid of the selected dominant follicles and of the large atretic ones after superovulatory treatment of goats are illustrated in Fig. 3. After superovulatory treatment with the FSH preparation, progesterone levels in the follicular fluid of the large atretic follicles significantly increased $(P<0.01)$ as compared to the selected dominant ones.

\section{Discussion}

In vivo experiments on sheep ovaries using surface follicle marking with Chinese ink, destruction of surface follicles by cautery and investigations into the effects of induced luteolysis or hormonal preparations (Dufour et al. 1979; Mc Natty et al. 1981, 1982; Driancourt et al. 1985) provided objective support for the statement according to which of the population of growing healthy tertiary follicles only those having a diameter surpassing $2 \mathrm{~mm}$ were capable of starting recruitment. Follicles with a diameter below $2 \mathrm{~mm}$ reveal a low sensitivity to the process of recruitment. This fact corresponds with the observation of follicle growth up to $0.2 \mathrm{~mm}$ even in hypophysectomized ewes (Dufour et al. 1979).

Forty-eight hours after cloprostenol treatment the overall number of tertiary recruited follicles and especially the number of surface follicles as well as the simultaneously increased number of less-than-2-mm follicles testify to the occurrence of a new cohort of tertiary follicles on the trajectory of growth (Driancourt et al. 1985; Presl and Bukovský 1989ab). 
Comparison of the effects of the post-luteolytic follicular phase on tertiary follicle populations as well as correlation analysis revealed the changes in the numbers of recruited follicles to be less variable and those in the numbers of selected follicles to be of increased variability. Those mechanisms that help to select a recruited follicle as a dominant one whereas other follicles undergo atresia, have not yet been elucidated. In most cases (about $70 \%$ ) it is the largest normal healthy tertiary follicle that is selected during luteolysis. This, however, is not a general rule as observations have evidenced that some large follicles do not need to reach the optimum level of complex qualitative parameters. Other, smaller follicles may have more suitable parameters enabling them to reach dominance in the preovulatory stage of development and maturation from the viewpoint of morphological properties (number and quality of granulosa cells) as well as functional endocrine (gonadotrophic receptors, quality and capacity) and immune (cytokines including IL-1, IGF-1, EGF and TGF) properties (Driancourt et al. 1985; Presl and Bukovský 1989ab; Seamark et al. 1992).

Newly, the results of Rubianes et al. (1997) indicate that large follicles developing in the early luteal phase can be induced to ovulate in response to $\mathrm{GnRH}$ stimulation and resume normal luteal function. However, follicles present in the late luteal phase respond to GnRH only if luteolysis is induced prior to the administration of GnRH since the elevated circulating progesterone levels block the ovulatory respose to GnRH. Thus the endocrine milieu preceding an induced LH rise is more important in determining the ovulatory response than the size of the follicle.

In conclusion it can be stated that oestrus synchronization in ewes through the induction of luteolysis by synthetic prostaglandin - cloprostenol leads to the occurrence of a cohort of follicles on the trajectory of growth and development within a new follicular wave. Evaluation of the superovulatory response in sheep and goats demonstrated that FSH- and PMSG-based preparations affected the follicles after recruitment in the process of selection. The present results support the concept of the two-tier regulatory mechanism of folliculogenesis that accomplishes the differentiation of the dominant ovulatory tertiary follicle by the gradual process of recruitment and selection. Our findings point at a key role of luteolysis both in the process of recruitment and in the induction of selection during folliculogenesis in sheep.

\section{Kvantita a kvalita terciárnych folikulov bahníc a kôz po synchronizácii ruje a superovulácii}

V práci boli vykonané kvantitatívne a kvalitatívne analýzy zmien terciárnych folikulov v priebehu ich rastových a vývojových vín oviec a kôz na vaječníkoch, hlavne folikulárneho náboru a výberu. Pozorovania a hodnotenia sa vykonali: (1) po luteolytickom ošetrení oviec plemena slovenská cigája (SC) prípravkom na báze cloprostenolu (syntetický $\mathrm{PGF}_{2 \alpha}$ ) a (2) po indukcii superovulácie pomocou prípravkov na báze FSH a PMSG u oviec plemena slovenské merino (SM) a bielych krátkosrstých kôz. Cielom práce bolo prehíbit a rozšírit poznanie: (1) o selekcii dominantného ovulačného terciárneho folikulu v priebehu rastových vín a (2) o vplyve prípravkov na báze racemátu cloprostenolu, folitropínu (FSH) a extrahypofyzárneho gonadotropínu séra žrebných kobýl (PMSG) na terciárne folikuly oviec a kôz. V rozmedzí 48 a 120 hodín po injekcii $125 \mu \mathrm{g}$ kloprostenolu $\left(\mathrm{PGF}_{2 \alpha}\right)$ na povrchu vaječníkov bolo pozorované simultánne zmnoženie neatretických folikulov rovnako v štádiu náboru ako aj výberu dominantného folikulu. Priemerná velkost’ najväčšieho rastúceho dominantného, t. z. ovulačného folikulu, bola signifikantne zvýšená u bahníc 24 a 48 hodín po podaní kloprostenolu v porovnaní nielen s kontrolami ale tiež pokusnými skupinami 72 a 120 hodín po luteolytickom ošetrení. Na superovulačné ošetrenie sa zaznamenala responzia u $11(73,3 \%)$ kôz a $45(88,24 \%)$ oviec. Signifikantné 
rozdiely $(P<0,01)$ v ovulačnej odpovedi boli zaznamenané medzi prípravkami FSH $(9,6 \pm$ $3,8)$ a PMSG $(4,6 \pm 1,1)$ u oviec. Po superovulačnom ošetrení koncentrácia $17 \beta$-estradiolu vo folikulárnej tekutine selektovaných dominantných folikulov sa signifikantne zvýšila v porovnaní s velkými atretickými folikulmi $(P<0,001)$. Synchronizácia estru oviec bola uskutočnená kloprostenolom, ktorý indukoval novú folikulárnu vlnu. Tieto výsledky naznačujú, že luteolýza má klúčovú úlohu tak v procese náboru, ako aj v indukcii výberu v priebehu folikulogenézy oviec. Hodnotenie superovulačnej odpovede oviec a kôz demonštruje, že prípravky na báze FSH a PMSG pôsobia na folikuly po nábore v procese výberu dominantného preovulačného folikulu.

\section{References}

CAHILL, LP, MARIANA, JC, MAULEÓN, F 1979: Total follicular population in ewes of high and low ovulation rates. J Reprod Fert 55: 27 - 36

DI ZEREGA, GS, HODGEN, GD 1981: Folliculogenesis in the primate ovarian cycle. Endocrine Rev 2: 27 - 49

DOLEŽEL, R 1995a: Dynamika folikulárního vývoje na vaječnících v průběhu pohlavní aktivity domácích zvířat (Dynamics of follicular development on ovaries during sexual activity in domestic animals). Veterinářství $\mathbf{4 5}$ : $442-445$

DOLEŽEL, R 1995b: Řízení folikulárního vývoje v průběhu pohlavní aktivity u domácích zvîratat (Control of the follicular development during sexual activity in domestic animals). Veterinářství 45: 489-491

DRIANCOURT, MA 1985: Lack of between-follicle interactions in the sheep ovary. Reprod Nut Dev 34: 249-260

DRIANCOURT, MA, GIBSON, WR, CAHILL, LP 1985: Follicular dynamics throughout the oestrous cycle in sheep. A review. Reprod Nutr Dév 25 (1A): 1-5

DUFOUR, J, CAHILL, LP, MAULÉON, P 1979: Short- and long-term effects of hypophysectomy and unilateral ovariectomy on ovarian follicular populations in sheep. J Reprod Fert 57: 301-309

ERICKSON, GF 1986: The ovary: Basic principles and concepts. In: FELLING, P, BAXTER, JD, BROADUS, AE, FROHMAN, LA (Eds): Endocrinology and Metabolism, second edition, McGraw - Hill Book Co., New York, pp. $905-950$

GREENWALD, GS, TERRANOVA, PF 1988: Follicular selection and its control. In: KNOBIL, E, NEIL, J et al. (Eds): The Physiology of Reproduction. Raven Press, Ltd, New York, pp. 387-445

MARAČEK, I, ELEČKO, J, CHOMA, J, BEKEOVÁ, E 1983: Folikulárny systém vaječníkov po synchronizácii ruje luteolytickým pôsobením cloprostenolu. (The follicular system of bovine ovaries after oestrus synchronisation by the luteolytic action of cloprostenol). Vet Med (Praha) 28: 705-716

MARAČEK, I, ELEČKO, J, HENDRICHOVSKÝ, V, LAZÁR, L, KRAJNIČÁKOVÁ, M, SCHWARC, F, SEREGI, J, TRENER, A, GÁBRIŠ, G 1989: Hormonálna príprava kôz pri úspešnom embryotransfere v podmienkach velkochovu (Hormonal preparation of goats for successful embryotransfer under large-scale breeding conditions). Veterinářství 39: 199-202

MARAČEK, I, HENDRICHOVSKÝ, V, BODNÁR, V, LAZÁR, L 1993: Najväčší zrejúci, neatretický terciárny folikul vaječníkov oviec v priebehu selekcie po podaní cloprostenolu v luteálnej fáze pohlavného cyklu. (The largest non-atretic tertiary follicle of sheep ovaries during slection after cloprostenol treatment in the luteal phase of the oestrouz cycle). Zborník vedeckých prác ÚEVM Košice, 9: 55-66

MCNATTY, KP, GIBB, M, DOBSON, C, THURLEY, DC 1981: Evidence that changes in luteinizing hormone secretion regulate the growth of the preovulatory follicle in the ewe. J Endocr 90: 375-389

McNATTY, KP, GIBB, M, DOBSON, C, BALL, K, COSTER, J HEATH, D, THURLEY, DC 1982: Preovulatory follicular development in sheep treated with PMSG and/or prostaglandin. J Reprod Fert 65: 11-123

MURDOCH, WJ 1985: Follicular determinants of ovulation in the ewe. Dom Anim Endocr 2: 105-121

MURDOCH, WJ 1988: Disruption of cellular associations within the granulosal compartment of periovulatory ovine follicles: Relationship to maturation of the oocyte and regulation by prostaglandins. Tiss Res 252: 459-462

PRESL, J, BUKOVSKY, A1989a: Selekce dominantního folikulu I (Selection of the dominant follicle 1-st part). Čs gynek 54: 200-214

PRESL, J, BUKOVSKY, A 1989b: Selekce dominantního folikulu II (Selection of the dominant follicle 2-nd part). Čs gynek 54: 284-300

RUBIANES, E, BEARD, A, DIERSCHKE, DJ, BARTLEWSKI, P, ADAMS, GP, RAWLINGS, NC 1997: Endocrine and ultrasound evaluation of the response to $\mathrm{PGF}_{2 \alpha}$ and $\mathrm{GnRH}$ given at different stages of the luteal phase in cyclic ewes. Theriogenology 48: 1093-1104

SEAMARK, RF, HADJISAVAS, M, ROBERTSON, SA1992: Influence of the immune system on reproductive function. Anim Reprod Sci 28: 171-173

SOKAL, RR, ROHLF, FJ 1969: Biometry. The principles and practices of statistics in biological research. San Francisco, Freeman and Co. pp.

TREUER, Á, BÉNYEI, B, KUHHOLZER BRIGIT, LÓZSI, P, SEREGI, J, BREM, G, RUDÓ, J 1997: Kecskeembriók sikeres átültetése (Successful transfer of goat's embryos). Magy Állatorv Lapja 119: 395-397 